\title{
Spatial and temporal variations of meiofaunal communities from the western sector of the Gulf of Batabanó, Cuba: II. Seagrass systems
}

\author{
Maickel Armenteros ${ }^{1}$, Jason Paul Williams ${ }^{2}$, Boris Creagh ${ }^{3} \&$ Norberto Capetillo \\ 1 Centro de Investigaciones Marinas, Universidad de La Habana, 16 \# 114, CP 11300, Playa, Ciudad Habana, Cuba; \\ maickel@cim.uh.cu \\ 2 Facultad de Biología, Universidad de La Habana, 25 \# 10, CP 10400, Plaza, Ciudad Habana, Cuba; \\ jaypwill@gmail.com \\ 3 Facultad de Biología, Universidad de La Habana, 25 \# 10, CP 10400, Plaza, Ciudad Habana, Cuba. \\ 4 Centro de Investigaciones Pesqueras, Ministerio de La Industria Pesquera, 5ta ave. y 246, CP 19100, Ciudad Habana, \\ Cuba; norberto@cip.telemar.cu
}

Received 19-X-2006. Corrected 10-X-2007. Accepted 22-VIII-2007.

\begin{abstract}
The meiofauna from seagrass meadows in the western sector of the Gulf of Batabanó, Cuba were studied to describe the spatial and temporal variations in community structure. Replicated cores were taken in three locations (arranged in $\mathrm{m}$ - and km-scales) and in two seasons (dry and wet). The meiofauna (metazoans between 500 and $45 \mu \mathrm{m}$ ) were identified to major taxa. Temporal changes in the meiofaunal communities could not be detected and they are not linked to the subtle seasonal changes in the water column. A larger variation in community structure was observed in the spatial $\mathrm{m}$-scale (among cores in a station) probably accredited to heterogeneity of microenvironment and biological processes. A second source of variation in the km-scale (among locations) was identified relating to physical processes affecting seagrass meadows: marine currents and anthropogenic disturbances. Distribution patterns of meiofauna across locations coincide with one study from 20 years ago in seagrass beds (i.e. higher densities in area closer to break-shelf and diminution of fauna at southern of Pinar del Río); however, cumulative anthropogenic disturbances on seagrass meadows would most likely explain the depletion of communities observed in our survey in comparison with decades ago. Estimates of meiofaunal density and richness of major taxa from our study (and other areas from the Cuban shelf) are consistently lower than other temperate and tropical sites; possibly caused by low primary productivity due to narrow tidal amplitude and oligotrophic waters. Rev. Biol. Trop. 56 (1): 55-63. Epub 2008 March 31.
\end{abstract}

Key words: meiofauna, seagrass meadows, Caribbean Sea, spatial distribution.

Seagrass systems are extensive beds of marine flowering plants bordering broad tropical and temperate regions of the World's Oceans. These systems play an important role in maintaining biological productivity and biogeochemical cycles in the sea (Hemminga and Duarte 2000) and support higher diversity and abundance of fauna in comparison to adjacent non-vegetated areas (Orth et al. 1984). An important path of the circulation of energy and matter in these ecosystems occurs through decomposition of detritus in sedimentary environment; where the complex detritus-bacteria- meiofauna system has a fundamental role (Danovaro 1996).

The meiofauna (defined here as metazoans passing through a $500 \mu \mathrm{m}$ and retained in a 45 $\mu \mathrm{m}$ sieve) are considered as a key metazoan group in marine sediments. They have two major ecological roles in seagrass beds (modified from Coull 1999): a) decomposition of organic matter and regeneration of nutrients and b) as a food source for higher trophic levels. The communities of meiofauna exhibit a remarkable temporal variation in vegetated areas principally linked to seasonal changes 
in primary production and decomposition of detritus (Danovaro 1996, Danovaro and Gambi 2002). Also, scale-dependent spatial variations have been reported in several studies of meiofauna (e.g. Hodda 1990, Li et al. 1997, De Troch et al. 2006). Due to the important role of meiofauna in the dynamic of seagrass meadows and also to their scale-dependent variability, studies on their abundance and distribution across different spatial scales should be important for the management of this habitat.

Information on meiofaunal communities in seagrass meadows is scarce when compared to other shallow tropical habitats or to the macrofauna from the same type of habitat (De Troch et al. 2001). In subtropical seagrass systems several studies on meiofauna have been carried out (e.g. Hopper and Meyer 1967, Bell et al. 1984, Hicks 1986, Gómez-Noguera and Hendrickx 1997), whereas comparatively fewer studies from tropical seagrass meadows exist (e.g. Guerrini et al. 1998, Ndaro and Olafsson 1999, De Troch et al. 2001, 2006). As a result, the ecological factors that determine the temporal and spatial distribution of meiofauna in tropical seagrass meadows are largely unknown. The lack of relevant information makes the meiofaunal global trends along tropical seagrass systems difficult to determine hence, demanding further investigations into these topics and a comparative analysis with previous studies.

The present research is part of an initial approach to the survey of meiofaunal communities in the Gulf of Batabanó, Cuba and it is preceded by a study on mangroves systems in the same area (Armenteros et al. 2006). Also, the study of meiofauna pertaining to several habitats from the Gulf of Batabanó is integrated in a larger project focused on the understanding of the dynamics of ecosystems from here; the most productive region of the Cuban shelf. Knowledge on the ecological structure and processes in this ecosystem is needed in order to properly manage the fisheries resources within the Gulf; since some evidence exists of mismanagement of those. The most dramatic examples are the decline in the fishing industry (e.g. spiny lobster Panulirus argus, and lane snapper Lutjanus synagris) in the last decade (Baisre 2004).

We attempt in the present paper to: (i) describe the temporal and scale-dependent spatial fluctuations in meiofaunal community structures; and (ii) compare the density estimates of meiofauna in the studied seagrass systems with other studies from tropical regions.

\section{MATERIALS AND METHODS}

Study zone: three locations were selected in the western sector of the Gulf of Batabanó, Cuba. Two of them, Dayaniguas (22 $17^{\prime} 07^{\prime \prime}$ $\left.\mathrm{N}, 83^{\circ} 16^{\prime} 58^{\prime \prime} \mathrm{W}\right)$ and Coloma $\left(22^{\circ} 11^{\prime} 33^{\prime \prime} \mathrm{N}\right.$, $\left.83^{\circ} 35^{\prime} 08^{\prime \prime} \mathrm{W}\right)$, located at the southern coast of the province of Pinar del Río and subjected to putative anthropogenic impact from rivers, creeks and coastal settlements. The third, named Isla, is located on the eastern side of the Isla de la Juventud (213' $32^{\prime \prime} \mathrm{N}, 82^{\circ} 33^{\prime} 58^{\prime \prime}$ $\mathrm{W})$; here it is far from major human settlements and closer to the shelf break. The locations have extensive seagrass meadows dominated by Thalassia testudinum Koenig, but other species of seagrass also appear in lesser abundance (e.g. Siringodium filiforme Kuetzing). Several common genera of macroalgae (e.g. Laurencia, Halimeda and Udotea) were associated with the studied seagrass beds. The bottoms were soft and the percent of silt + clay in each location were 57, 41 and $24 \%$ for Dayaniguas, Coloma and Isla respectively.

Sampling design: a design was carried out in order to detect spatial variations of meiofauna in several scales: i) tens of $\mathrm{km}$ (i.e. between locations); ii) few $\mathrm{km}$ (i.e. between sampling stations within the same location; $1-10 \mathrm{~km}$ ); and iii) tens of meters (between cores (replicates) within the same sampling station). Samples were taken in the year 2003 in two months: February (dry season) and July (wet season). Two sampling stations were located in both Dayaniguas and Isla while there were three in Coloma; all of them were located 
2-4 $\mathrm{km}$ from the coast line, which in all the cases was bordered by mangrove forests.

Within each sampling station four cores were taken at random; the minimum distance between where one core was taken from the other was $5 \mathrm{~m}$ while the maximum was $25 \mathrm{~m}$. The corer was a plastic syringe $(50 \mathrm{~mL})$ with an area of $5.3 \mathrm{~cm}^{2}$. To obtain the samples the corer was buried into the sediment to a depth of 10 $\mathrm{cm}$. In each sampling station, a single measurement of temperature, salinity, dissolved oxygen (DO), $\mathrm{pH}$ and water depth $(10 \mathrm{~cm}$ from the bottom) was carried out using an oceanographic probe 4a from Hydrolab Inc. The percent of silt + clay was determined in each location on November, 2003 by sieving sediments through a $63 \mu \mathrm{m}$ mesh and expressing the weight of the material that passed through as a fraction of the whole weight of the sample.

Sample processing: samples of meiofauna were stored in polyethylene bags with buffered formalin at $4 \%$. In the laboratory the samples were sieved through 500 and $45 \mu \mathrm{m}$ sieves. The sediment retained in the later was kept (for meiofauna extraction) and the remaining fraction disposed. The extraction of animals from sediments was carried out by a flotation technique in a high density solution (commercial sugar crystals added to filtered water to a density of $1.18 \mathrm{~g} \mathrm{~cm}^{-3}$ ). Each sample was decanted at least three times. The samples were stained with alcoholic eosin (1\%) in order to facilitate the detection of animals; the identification to higher taxa (e.g. nematodes, copepods) and the quantification of animals were done under a stereoscopic microscope MBC-9 (56X maximum).

Data analysis: nested analyses of variance and t-test were applied in order to test differences in univariable measures of communities: density of major taxa and total density. T-test were performed for test differences between seasons (dry-wet); nested ANOVA were done for detect differences among stations (scale: few $\mathrm{km}$ ) nested locations (scale: tens of $\mathrm{km}$ ). Data was transformed $(\log \mathrm{x}+1)$ to reduce/ eliminate the correlation mean-variance. The software PRIMER 5.2.9 (Clarke and Warwick 2001) was used for multivariate analysis. The numerical ordination of samples of meiofauna based on density data was done by nonmetrical multidimensional scaling (nmMDS); the data were transformed by square-root in order to reduce contributions of dominant taxa, and therefore to increase the importance of less abundant ones. The similarity coefficient of Bray-Curtis was selected for the construction of similarity matrices. Permutations-based hypothesis tests (ANOSIM) were performed (using the same similarity matrix of nmMDS) in order to test statistical differences in the community structure relating to analyzed factors: month (two levels), location (three levels) and station (nested within location). Each ANOSIM test was performed using 999 permutations as maximum. An ordination of samples was carried out using a correlation-based principal component analysis (PCA) on basis of abiotic variables; these ones were standardized due to presence of different units of measurement.

\section{RESULTS}

The abiotic factors exhibited a small seasonal variation in temperature, $\mathrm{pH}$, salinity and dissolved oxygen between February and July (Fig. 1 and table 1). Dry season (February) shows lower values (average in brackets $\pm \mathrm{SE}$ ) of temperature $\left(28.3 \pm 0.1^{\circ} \mathrm{C}\right), \mathrm{pH}(8.18 \pm 0.05)$ and DO $\left(6.7 \pm 0.1 \mathrm{mg} \mathrm{L}^{-1}\right)$ and higher values of salinity $(36.5 \pm 0.2 \%$ ) in comparison with the wet season. July was characterized by higher values of temperature $\left(29.8 \pm 0.1^{\circ} \mathrm{C}\right), \mathrm{pH}(8.75$ $\pm 0.02)$ and DO $\left(7.3 \pm 0.2 \mathrm{mg} \mathrm{L}^{-1}\right)$ and lower values of salinity $(31.6 \pm 0.7 \%$ ).

Six major meiofaunal taxa were recorded in the two sampled months: Nematoda, Copepoda, Polychaeta, Ostracoda, Acari and Tanaidacea. The averaged number of major taxa for each combination of location-month was notably low (minimum: 2 and maximum: 4) and there was not a clear pattern of variation in the number of higher taxa across location 


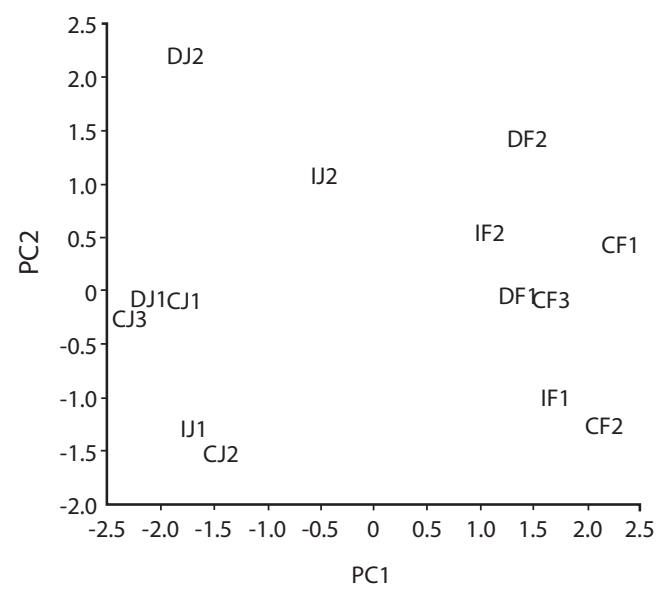

Fig. 1. PCA ordination plot of samples on basis of abiotic variables measured in Gulf of Batabanó, Cuba. The sample labels: first type: locations $(\mathrm{D}=$ Dayaniguas, $\mathrm{C}=\mathrm{Coloma}$ and $\mathrm{I}=\mathrm{Isla})$; second type: months $(\mathrm{F}=$ February and $\mathrm{J}=\mathrm{July})$; number indicates the stations. Explained variance by first and second axes: $87.7 \%$. The equations of axes: $\mathrm{PC} 1=-0.54 \mathrm{~T}-0.53 \mathrm{pH}+0.50 \mathrm{~S}-0.43 \mathrm{DO}+0.026 \mathrm{~d}$. PC2 $=$ $0.89 \mathrm{~d}-0.37 \mathrm{DO}-0.26 \mathrm{~S}-0.03 \mathrm{~T}+0.02 \mathrm{pH}$. T=temperature; $\mathrm{S}=$ salinity; $\mathrm{DO}=$ dissolved oxygen and $\mathrm{d}=$ depth.

or month (Fig. 2). Nematodes and copepods constitute more than $95 \%$ of the total density of fauna (all averaged cores) and possessing mean values ( $\pm \mathrm{SE}, \mathrm{N}=51$ cores) of $90.0 \pm 2.3$ and $4.9 \pm 1.2 \%$ respectively. The density of total meiofauna (all taxa summed) ranged from 0 to 466.8 individuals per $10 \mathrm{~cm}^{2}$; and the mean value of density (all cores averaged) was $56.6 \pm$ 10.1 individuals per $10 \mathrm{~cm}^{2}$.
According to a t- test performed with non-transformed data (due to the existence of homogeneity of variance) and 52 degrees of freedom, there were no differences between months in the density of nematodes, copepods and total meiofauna (all taxa summed). The results of t-values (the probability in brackets) were $-0.73(0.47) ;-0.32(0.75)$ and $-0.76(0.45)$ respectively for each variable. A two-way nested ANOVA (pooling across two months) was applied in order to detect differences between stations nested within locations for the variables: density of (i) nematodes, (ii) copepods and (iii) total meiofauna. The variables were transformed as $\log (\mathrm{x}+1)$ in order to eliminate correlation between mean-variance; it was successfully. The results of the ANOVA indicated significant differences between locations, the F- values (probabilities in brackets): $8.13(<0.001), 5.63(0.006)$ and $8.11(0.001)$ respectively for the variables nematodes, copepods and total meiofauna. The ANOVA failed to detect differences between stations for the variables nematodes and copepods: $2.11(0.13)$, and 1.09 (0.37), but found differences for the variable total meiofauna $(\mathrm{F}=3.04 ; \mathrm{p}=0.02)$. The amount of variation associated with each source (measured as the sum of squares) indicates that, for any of the three variables, the location was responsible for nearly a quarter of the total variation (18-23\%). The variation associated with the stations is relatively low (8-17\%) and the variation associated with the error (between

TABLE 1

Mean values \pm standard error of abiotic variables measured in Gulf of Batabanó, Cuba

\begin{tabular}{llcccccc} 
Location & Month & $\mathrm{N}$ & $\mathrm{T}\left({ }^{\circ} \mathrm{C}\right)$ & $\mathrm{S}(\%)$ & $\mathrm{DO}\left(\mathrm{mg} \mathrm{L}^{-1}\right)$ & $\mathrm{pH}$ & Depth $(\mathrm{m})$ \\
Dayaniguas & February & 2 & $28.1 \pm 0.2$ & $35.8 \pm 0.3$ & $6.87 \pm 0.19$ & $8.22 \pm 0.06$ & $2.3 \pm 0.5$ \\
& July & 2 & $30.0 \pm 0.0$ & $30.0 \pm 2.0$ & $7.17 \pm 0.53$ & $8.72 \pm 0.03$ & $3.1 \pm 0.7$ \\
\multirow{2}{*}{ Coloma } & February & 3 & $28.2 \pm 0.3$ & $36.6 \pm 0.01$ & $6.40 \pm 0.13$ & $8.15 \pm 0.02$ & $3.5 \pm 0.6$ \\
& July & 3 & $29.9 \pm 0.1$ & $31.5 \pm 0.8$ & $7.45 \pm 0.07$ & $8.75 \pm 0.02$ & $3.0 \pm 0.4$ \\
\multirow{2}{*}{ Isla } & February & 2 & $28.4 \pm 0.1$ & $37.0 \pm 0.02$ & $6.91 \pm 0.05$ & $8.19 \pm 0.19$ & $3.1 \pm 0.7$ \\
& July & 2 & $29.5 \pm 0.3$ & $33.4 \pm 0.1$ & $7.18 \pm 0.48$ & $8.79 \pm 0.05$ & $6.2 \pm 0.9$
\end{tabular}

$\mathrm{N}=$ number of observations. $\mathrm{T}=$ temperature, $\mathrm{S}=$ salinity, $\mathrm{DO}=$ dissolved oxygen. 


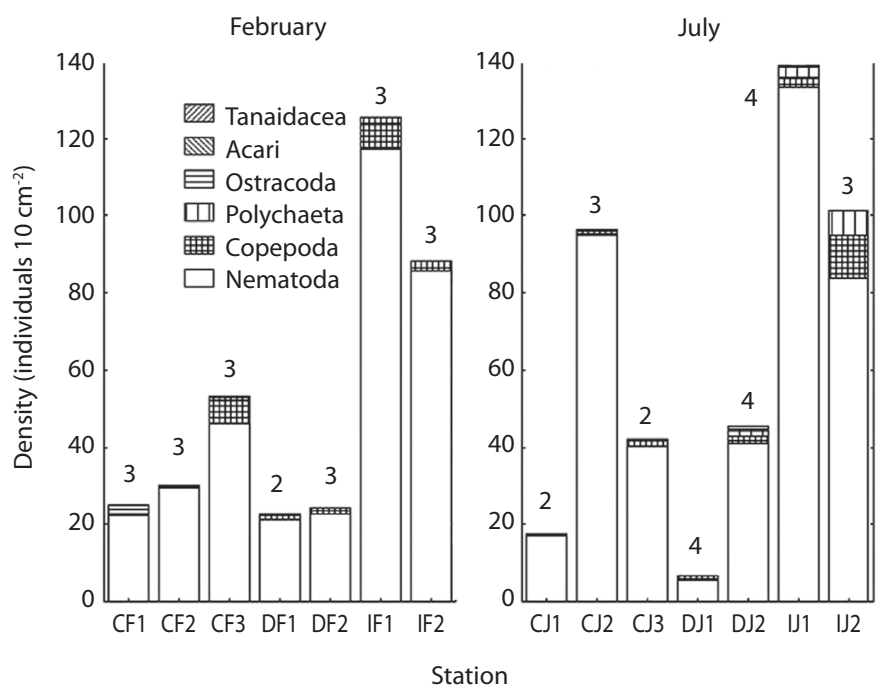

Fig. 2. Density of meiofauna in three locations and two months from Gulf of Batabanó, Cuba. Bars indicate the average ( $\mathrm{n}=4$ cores) for each station within locations. Numbers on top of the bars indicate the maximum number of recorded higher taxa. Sample labels: first type: locations $(\mathrm{C}=$ Coloma, $\mathrm{D}=$ Dayaniguas and $\mathrm{I}=\mathrm{Isla})$; second type: months $(\mathrm{F}=\mathrm{February}$ and $\mathrm{J}=\mathrm{July})$, number indicates the station.

cores/replicates) is larger $(61-75 \%)$. The differences between locations should be the result of a higher nematode and total density in the Isla location for both months (Fig. 2).

A one-way ANOSIM test indicated no differences between months $(\mathrm{R}=-0.01 ; \mathrm{p}=0.57$; 999 permutations). On the basis of these results a two-way nested ANOSIM was performed (with station nested within location) searching for differences in spatial distribution by scales. There are differences between stations $(\mathrm{R}=0.1$; $\mathrm{p}=0.03$; 999 permutations) but not between locations ( $\mathrm{R}=0.43 ; \mathrm{p}=0.09 ; 105$ permutations). The interpretation of the absolute $\mathrm{R}$ - value indicates that the variation component correspondent to locations is higher than the component associated with stations (i.e. the variation of meiofaunal community between sampling stations within each location is smaller than the variation between locations). This is in agreement with the results of univariate ANOVA. However, the probability values indicate no significant differences between locations probably due to the low number of permutations (i.e. low statistical power of the test). Due to the low number of replicates, pairwise test to determine differences between pairs of locations could not be done. The nmMDS ordination plot does not indicate clear segregations of any group of samples (Fig. 3) but the Isla location exhibits a lower sample dispersion in the plot (i.e. having a lower variability in community structure) when compared with other stations.

Both the multivariate and the univariate tests along with the graphical representations suggest that there was no significant seasonal change in the meiofaunal communities; however there were notable changes in meiofaunal communities for two of the tested spatial scales: tens of kilometers (among locations) and tens of meters (among cores). The nematodes and copepods are the principal contributors to the variation in the community structure; apparently, the remaining taxa exhibit variations at random.

\section{DISCUSSION}

The small amplitude of seasonal changes in the abiotic factors at the water bottom (e.g. $2{ }^{\circ} \mathrm{C} ; 4 \%$; $1 \mathrm{mgO}_{2} \mathrm{l}^{-1}$ ) suggests a little effect 


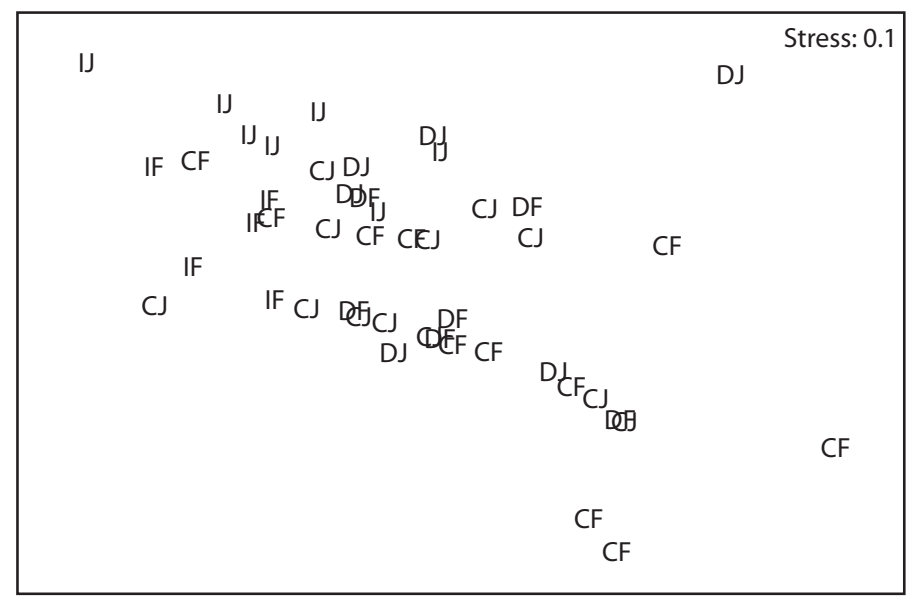

Fig. 3. MDS ordination plot for samples of meiofauna from three locations in the Gulf of Batabanó, Cuba. Data of density transformed as square root. Sample labels: first type: Locations $(\mathrm{C}=\mathrm{Coloma}, \mathrm{D}=$ Dayaniguas and $\mathrm{I}=\mathrm{Isla})$; second type: Months ( F=February and $\mathrm{J}=\mathrm{July}$ ). Three cores with zero animals and one outlier value were eliminated from ordination.

on the major features of the seagrass systems (e.g. primary production, cover of seagrass). According to Zieman et al. (1997), there are very low seasonal differences in the standing crop and in the productivity of Caribbean seagrass ecosystems in comparison with higher latitudes (e.g. Florida bay, Tampa). Temporal significant changes in the abiotic environment, when occur, would be often caused by random events (e.g. hurricanes or cold fronts) do not directly coupled to weather seasons (i.e. wet and dry).

The meiofauna in temperate seagrass habitats show seasonal changes of community structure as a response to sedimentary environment, particularly food availability which seems to be a key factor for the communities (Danovaro 1996, Danovaro and Gambi 2002). The more or less stable standing crop for tropical seagrasses by seasons does not signify that the production is homogeneous; instead the productivity fluctuates markedly causing temporal changes of meiofauna (Paula et al. 2001). Temporal changes of meiofauna in several time scales (daily, intra-seasonal, intra-annual) exist in subtropical estuarine ecosystems (Nozais et al. 2005); also they would occur in interaction with spatial variation in $\mathrm{km}$ - scales (Armenteros et al. 2006). In our study, lack of differences in meiofauna between dry and wet seasons was expected as consequence of (i) subtle seasonal environmental differences and (ii) high variance associated to several sources of scale-depending variation. Similar lack of a significant differences in temporal patterns has been founded in other studies where only two times of sampling have been performed (e.g. Dittmann 2000). However, in presence of strong seasonal events (e.g. Amazon river's discharge as in Aller and Stupakoff 1996), inter-seasonal changes in meiofauna would be clearly distinguished.

The low number of recorded taxa (only six) is probably due to: (i) a tendency of formalin to destroy "soft-body" meiofauna (e.g. Cnidaria, Turbellaria, Sipuncula, Gastrotricha) during delay phase (2-7 months) between collection and observation of samples, and (ii) low efficiency of sampling strategy (i.e. small size and number of cores) in collecting rare taxa. In other surveys in tropical seagrass around the world (e.g. De Troch et al. 2006) the number of taxa tends to be larger than eight and could be as high as 15. Previous studies in the Gulf of Batabanó (López-Cánovas 1990) reported 14-15 major meiofaunal taxa, although some of them also pertain to macrofauna (following the present definition of mesh size for 
meiofauna). Anyways, present study underestimate the diversity of meiofaunal taxa in the Gulf of Batabanó; the low number of recorded taxa excludes the possibility of any trend in this univariate measure of community arising across months or locations.

The present study recorded distributional patterns of meiofauna dependent on spatial scale. The maximum variation was associated to the tens of meters scale (i.e. among cores within a station), while the second rank in variation was among locations (tens of kilometers) and the lowest magnitude was observed among stations within a location $(1-10 \mathrm{~km})$. Physical factors (e.g. currents) may be more important in generating $\mathrm{km}$-scale heterogeneity in meiofauna than the biological - organic factors (e.g. patchy food distribution) (Li et al. 1997). In the Gulf of Batabanó, the factors that could be affecting the distribution of meiofauna in small scale (tens of meters) are possibly related with heterogeneity of microenvironment. Two important factors would be the distribution of decomposing organic matter in patches (e.g. seagrass leaves or dead bodies) and the gathering of individuals around enhanced habitat (e.g. holes of polychaetes). The effects of these factors - conditions during sampling are difficult to predict in the field; therefore at this small scale there should be a permanent and considerable source of variance in any sampling design. We suggest devoting strong sampling efforts (at least three cores) to $\mathrm{m}$-scale in order to detect spatial patterns at higher scales.

The spatial distributional pattern across locations in the present study is in accordance with results from meiofaunal studies in the same area from 20 years ago (López-Cánovas $1990)$; i.e. lower density of meiofauna in southern Pinar del Río in comparison with Isla. Two main abiotic processes should be responsible, at least partially, for the variation of community structure in the $\mathrm{km}$-scale (i.e. among locations): (i) oceanographic processes and (ii) human disturbance. A more intense renovation of water occurs in the eastern portion of Isla de La Juventud (Isla location) in comparison with the other locations from the southern region of
Pinar del Río (I. Pérez, pers. comm.); the input of oceanic waters from Caribbean Sea to the shelf probably enhances the primary production of seagrasses and the secondary production of benthos.

There is no conclusive evidence (e.g. measures of pollutant levels within a environmental impact study) that proves greater human disturbances in Dayaniguas and Coloma than in Isla. However, the higher variability in meiofaunal communities in seagrass meadows (present study) and in mangroves (Armenteros et al. 2006) from the southern Pinar del Río region suggests stress on meiofaunal communities, probably linked to anthropogenic disturbances from coastal settlement and effluents from rivers and creeks. The increase of variability in the community structure as response to anthropogenic stress has been stated by Clarke and Warwick (1993).

The depletion of meiofauna in the Gulf of Batabanó in terms of diversity and abundance of higher taxa in comparison with a study from 20 years ago (López-Cánovas 1990) would be related to cumulative degradation of seagrass meadows in this period. The density of meiofauna in the mentioned study probably was underestimated by the use of a higher mesh aperture $(100 \mu \mathrm{m})$; this reinforces the differences with our results.

In temperate and subtropical seagrass systems the density of nematodes and copepods is consistently higher than in the present study (see data from Bell et al. 1984, Ansari and Parulekar 1994 for references). Studies in tropical seagrass meadows (Ndaro and Olafsson 1999, De Troch et al. 2001, 2006) show higher meiofaunal density than the present study, López-Cánovas (1990) and additional data (unpublished from M. Armenteros) from the Cuban NW and SW shelf.

Tidal amplitude would be a key factor in determining the productivity of tropical seagrass systems and the abundance of meiofauna (De Troch et al. 2006). We state that narrow tidal amplitude in the Cuban shelf (less than $20 \mathrm{~cm}$ after Rodríguez and Rodríguez 1983) and oligotrophy of water and sediments 
(Lluis-Riera 1972) would be the causes, at least partially, of the low density of meiofauna in comparison with other tropical sites. Further surveys on the community structure of meiofauna along several sites with a wide range of tidal amplitude are necessary to prove or disprove this hypothesis.

In summary, we found scale-depending spatial distribution of meiofauna, with $\mathrm{km}$ scale possibly associated to physical processes (oceanographic and anthropogenic disturbances) and m-scales related to biological processes. We suggest that low estimates of meiofauna in comparison with other tropical sites would be caused by narrow tidal amplitude and oligotrophy of waters in the SW Cuban shelf.

\section{RESUMEN}

La meiofauna asociada a pastos marinos en el sector occidental del Golfo de Batabanó, Cuba se estudió para describir las variaciones espaciales y temporales en la estructura de la comunidad. Se tomaron muestras repetidas, a escala de $\mathrm{m}$ - y km, en tres localidades y en dos estaciones (seca y lluvia). La meiofauna (metazoos entre 500 y $45 \mu \mathrm{m}$ ) fue identificada hasta grupos taxonómicos principales. No se detectaron cambios estacionales en la estructura de las comunidades de meiofauna ni asociación con los factores abióticos en la columna de agua. La mayor variación en la estructura de la comunidad fue observada a escala espacial de metros (entre muestras en una estación), causada probablemente por la heterogeneidad del micro-ambiente y procesos biológicos. La segunda fuente de variación aparece en escala de kilómetros (entre localidades) y está relacionada a procesos físicos que afectan los pastos marinos: corrientes marinas y disturbios antropogénicos. Los patrones de distribución de la meiofauna a través de las localidades coinciden con un estudio de hace 20 años en pastos marinos (densidades mayores en las áreas más cercanas al borde de la plataforma y menores en el Sur de Pinar del Río); sin embargo, la acumulación de los efectos del impacto antropogénico probablemente explique la disminución de la densidad en las comunidades actuales de meiofauna. Los estimados de densidad de meiofauna y de riqueza de táxones en nuestro estudio (y en otras áreas de la plataforma de Cuba) son coherentemente más bajos que en otros sitios templados y tropicales; la causa posible es la baja productividad primaria debido a la estrecha amplitud de mareas y la oligotrofia de las aguas.

Palabras clave: meiofauna, pastos marinos, mar Caribe, distribución espacial.

\section{REFERENCES}

Aller, J.Y. \& I. Stupakoff. 1996. The distribution and seasonal characteristics of benthic communities on the Amazon shelf as indicators of physical processes. Cont. Shelf Res. 16: 717-751.

Ansari, Z.A. \& A.H. Parulekar. 1994. Meiobenthos in the sediments of seagrass meadows of Lakshadweep atolls, Arabian Sea. Vie Milieu 44: 185-190.

Armenteros, M., I. Martín, J.P. Williams, B. Creagh, G. González-Sansón \& N. Capetillo. 2006. Spatial and temporal variations of meiofaunal communities from the western sector of the Gulf of Batabanó, Cuba. I. Mangrove systems. Estuaries Coasts 29: 124-132.

Baisre, J.A. 2004. La pesca marítima en Cuba. Científico Técnica, La Habana, Cuba.

Bell, S.S., K. Walters \& J.C. Kern. 1984. Meiofauna from seagrass habitats: A review and prospectus for future research. Estuaries 7: 331-338.

Clarke, K.R. \& R.M. Warwick. 2001. Change in marine communities. An approach to statistical analysis and interpretation. PRIMER-E, Plymouth, England.

Coull, B.C. 1999. Role of meiofauna in estuarine softbottom habitats. Austr. J. Ecol. 24: 327-343.

Danovaro, R. 1996. Detritus-Bacteria-Meiofauna interactions in a seagrass bed (Posidonia oceanica) of the NW Mediterranean. Mar. Biol. 127: 1-13.

Danovaro, R. \& C. Gambi. 2002. Biodiversity and trophic structure of nematode assemblages in seagrass systems: evidence for a coupling with changes in food availability. Mar. Biol. 141: 667-677.

De Troch, M., D. Van Gansbeke \& M. Vincx. 2006. Resource availability and meiofauna in sediment of tropical seagrass beds: Local versus global trends. Mar. Environ. Res. 61: 59-73.

De Troch, M., S. Gurdebeke, F. Fiers \& M. Vincx. 2001. Zonation and structuring factors of meiofauna communities in a tropical seagrass bed (Gazi Bay, Kenya). J. Sea Res. 45: 45-61.

Dittmann, S. 2000. Zonation of benthic communities in a tropical tidal flat of north-east Australia. J. Sea Res. 43: 33-51.

Gómez-Noguera, S.E. \& M.E. Hendrickx. 1997. Distribution and abundance of meiofauna in a subtropical coastal lagoon in the South-eastern Gulf of California, Mexico. Mar. Pollut. Bull. 34: 582-587. 
Guerrini, A., M.A. Colangelo \& V.U. Ceccherelli. 1998. Recolonization patterns of meiobenthic communities in brackish vegetated and unvegetated habitats after induced hypoxia/anoxia. Hydrobiologia 375/376: 73-87.

Hemminga, M.A. \& C.M. Duarte. 2000. Seagrass Ecology. Cambridge, Cambridge, UK.

Hicks, G.R.F. 1986. Distribution and behaviour of meiofaunal copepods inside and outside seagrass beds. Mar. Ecol. Prog. Ser. 31: 159-170.

Hodda, M. 1990. Variation in estuarine littoral nematode populations over three spatial scales. Estuar. Coast. Shelf Sci. 30: 325-340.

Hopper, B.E. \& S.P. Meyers. 1967. Populations studies on benthic nematodes within a subtropical seagrass community. Mar. Biol. 1: 85-96.

Li, J., M. Vincx, P.M.J. Herman \& C. Heip. 1997. Monitoring meiobenthos using $\mathrm{cm}-, \mathrm{m}-$ and $\mathrm{km}-$ scales in the southern Bight of the North Sea. Mar. Environ. Res. 43: 265-278.

Lluis-Riera, M. 1972. Estudios hidrológicos del Golfo de Batabanó y de las aguas oceánicas adyacentes. Serie Oceanológica Academia de Ciencias de Cuba 14: s.p.

López-Cánovas, C. 1990. Características generales del meiobentos de la macrolaguna del Golfo de Batabanó, p. 100-111. In P.M. Alcolado (ed.). El bentos de la macrolaguna del Golfo de Batabanó. Academia, La Habana, Cuba.

Ndaro, S.G.M. \& E. Ólafsson. 1999. Soft-bottom fauna with emphasis on nematode assemblage structure in a tropical intertidal lagoon in Zanzibar, eastern Africa: I. Spatial variability. Hydrobiologia 405: 133-148.

Nozais, C., R. Perissinotto \& G. Tita. 2005. Seasonal dynamics of meiofauna in a South African temporarily open/closed estuary (Mdloti Estuary, Indian Ocean). Estuar. Coast. Shelf Sci. 62: 325-338.

Orth, R.J., K.L.J. Heck \& J. van Montfrans. 1984. Faunal communities in seagrass beds: a review of the influence of plant structure and prey characteristics on predator-prey relationships. Estuaries 7: 39-350.

Paula, J., P. Fidalgo, E. Costaa, A. Martins \& D. Gove. 2001. Patterns of abundance of seagrasses and associated infaunal communities at Inhaca Island, Mozambique. Estuar. Coast. Shelf Sci. 53: 307-318.

Rodríguez, J.P. \& J.E. Rodríguez. 1983. Las mareas en las costas cubanas. Rep. Invest. Inst. Oceanol. Acad. Cienc. Cuba 6: s.p.

Warwick, R.M. \& K.R. Clarke. 1993. Increased variability as a symptom of stress in marine communities. J. Exp. Mar. Biol. Ecol. 172: 215-226.

Zieman, J., P. Penchaszadeh, J.R. Ramírez, D. Pérez, D. Bone, J. Herrera-Silveira, R.D. Sánchez-Arguelles, D. Zuniza, B. Martínez, P. Alcolado-Menéndez, K. Bonair, R. Laydoo, J.R. García, J. Garzón-Ferreira, G. Díaz, P. Gayle, D.T. Gerace, G. Smith, H. Oxenford, C. Parker, L.P.J.J. Pors, J.A. Nagelkerken, B. Van Tussenbroek, S.R. Smith, R. Varela, K. Koltes \&J. Tschirky. 1997. Variation in ecological parameters of Thalassia testudinum across the CARICOMP network, p. 663-668. In H.A. Lessios $\&$ I.G. Macintyre (eds.). Proceedings of $8^{\text {th }}$ Coral Reef Symposium Vol. 1. Smithsonian Tropical Research Institute, Panama. 
